\title{
Influence of the Conditions of Exposure of Pigs Carcasses (Sus scrofa domesticus L.) on the Egg-Laying Delay of Necrophagous Diptera in the Guinean Zone of Ivory Coast
}

\author{
Kpama-Yapo Yapibie Carine Eurudice ${ }^{1, ~ *, ~ D a o ~ H a s s a n e ~}{ }^{1}$, Koffi Alexandre Franklin², \\ Aboua Louis Roi Nondenot ${ }^{1}$ \\ ${ }^{1}$ Department of Biosciences, Laboratory for Natural Environments and Biodiversity Conservation, Felix Houphouet Boigny University of \\ Cocody, Abidjan, Ivory Coast \\ ${ }^{2}$ National Institute of Public Hygiene (INHP), Anti Vector Control Service, Abidjan, Ivory Coast
}

\section{Email address:}

carineyapo85@yahoo.fr (Kpama-Yapo Y. C. E.), daohassane1@gmail.com (Dao H.), koffialexandref@yahoo.fr (Koffi A. F.), aboualr@hotmail.com (Aboua L. R. N.)

${ }^{*}$ Corresponding author

\section{To cite this article:}

Kpama-Yapo Yapibie Carine Eurudice, Dao Hassane, Koffi Alexandre Franklin, Aboua Louis Roi Nondenot. Influence of the Conditions of Exposure of Pigs Carcasses (Sus scrofa domesticus L.) on the Egg-Laying Delay of Necrophagous Diptera in the Guinean Zone of Ivory Coast. American Journal of Entomology. Vol. 4, No. 4, 2020, pp. 66-73. doi: 10.11648/j.aje.20200404.12

Received: November 25, 2020; Accepted: December 16, 2020; Published: December 22, 2020

\begin{abstract}
A decaying cadaver is particularly attractive to necrophagous insects, more specifically Diptera. These are the first to lay their eggs on corpses. For the post mortem interval determination, the entomologist needs to know the precise time of the first egg-laying. The objective of this study is to determine the egg laying delay of these insects on a cadaver exposed in different conditions in the Guinean zone of Côte d'Ivoire. To do this, our work was been carried out in a natural environment at the National Agronomic Research Center. The experimental setup consisted of four types of wire mesh cages corresponding to the following cases: cadavers exposed to the open air or control cadavers, semi-immersed cadavers, cadavers wrapped in a shroud and suspended cadavers. Work on the site has been made from 29 October to 5 November 2019. The spawning period in species of Calliphoridae, was shorter on control and suspended cadavers. In Sarcophagidae, we noted a larviposition late on the suspended cadavers. Muscidae and Fanniidae, which intervened later on the decomposing corpses, were not observed on the suspended cadavers. These carcasses quickly dried out, no longer being able to provide nutrients essential for the proper development of larvae of species of these Diptera families. Depending on the accessibility of the corpses to necrophagous insects, the first egg-laying of Diptera were observed after 6 hours of exposure and the last after 174 hours. The exposure conditions of the corpses significantly influenced the time taken to lay the main necrophagous Diptera. As the first egg-laying of the flies occurs in the first moments after death, as long as the corpses is accessible, the results obtained during these experiments should be taken into account by the expert entomologist, in the estimation of the interval post-mortem upon discovery of a corpse.
\end{abstract}

Keywords: Eggs-Laying Delay, Necrophagous Diptera, Corpses, Guinean Zone, Ivory Coast

\section{Introduction}

A decomposing corpse attracts a large and diverse fauna. This is particularly composed of necrophagous insects, in particular Diptera, whose activities allow the post-mortem interval to be estimated. The spawning involved in the first moments after death [1]. The eggs are laid in or in the immediate vicinity of the natural orifices of the cadaver [2,
3]. Knowledge of the data relating to the lengths of the development cycles of fly species and to the various environmental conditions will enable investigators to determine the dates of the first flies laying eggs [4]. Nevertheless, the triggering of egg laying depends on the state of the corpses and the pre-existing egg laying on the 
cadaver [5]. The determination of the egg-laying delay can be influenced by bad climatic conditions, or human action [6]. The degradation of a corpses and its colonization by insects are two closely related phenomena and are influenced by many factors intrinsic and extrinsic to the cadaver [5, 7]. The post-mortem interval (PMI) is the time elapsed between the moment of death and the discovery of the corpse [4]. The investigations carried out for the determination of the PMI through several studies in Asia, America, Europe and South Africa, made it possible to establish databases. In Côte d'Ivoire, the work carried out by [8-12] made it possible to establish a local database of necrophagous Diptera, but the literature does not mention any data on necrophagous dipterans' egg laying delay on corpses. This study is part of a perspective of enriching this database of necrophagous Diptera. The objective of this study is to determine the egglaying delay of these insects on a cadaver exposed in different conditions in the Guinean zone of Ivory Coast.

\section{Material and Methods}

\subsection{Study Site}

The work was carried out at the National Agronomic Research Center (NARC), located west of the city of Abidjan, precisely in Adiopodoumé at $\mathrm{km} 17$. The experimental site $\left(5^{\circ}\right.$ $19^{\prime} 40.13^{\prime \prime} \mathrm{N}-4^{\circ} 07^{\prime} 54,80^{\prime \prime} \mathrm{W}$ - Altitude $17 \mathrm{~m}$ ) is limited to the south and east by the Ebrié lagoon, to the west by the road leading to the Institut Pasteur in Adiopodoumé and to the north by the road which leads to Dabou. It covers an area of approximately 230 hectares. There is vegetation essentially made up of a relic of primary lagoon forest covering $4 / 5$ of the site. In its western part, a fringe of this forest relic has undergone severe degradation under the action of man to make way for vegetation made up of grasses and cassava plantations. This site houses many buildings for administration and accommodation for the agents who work there.

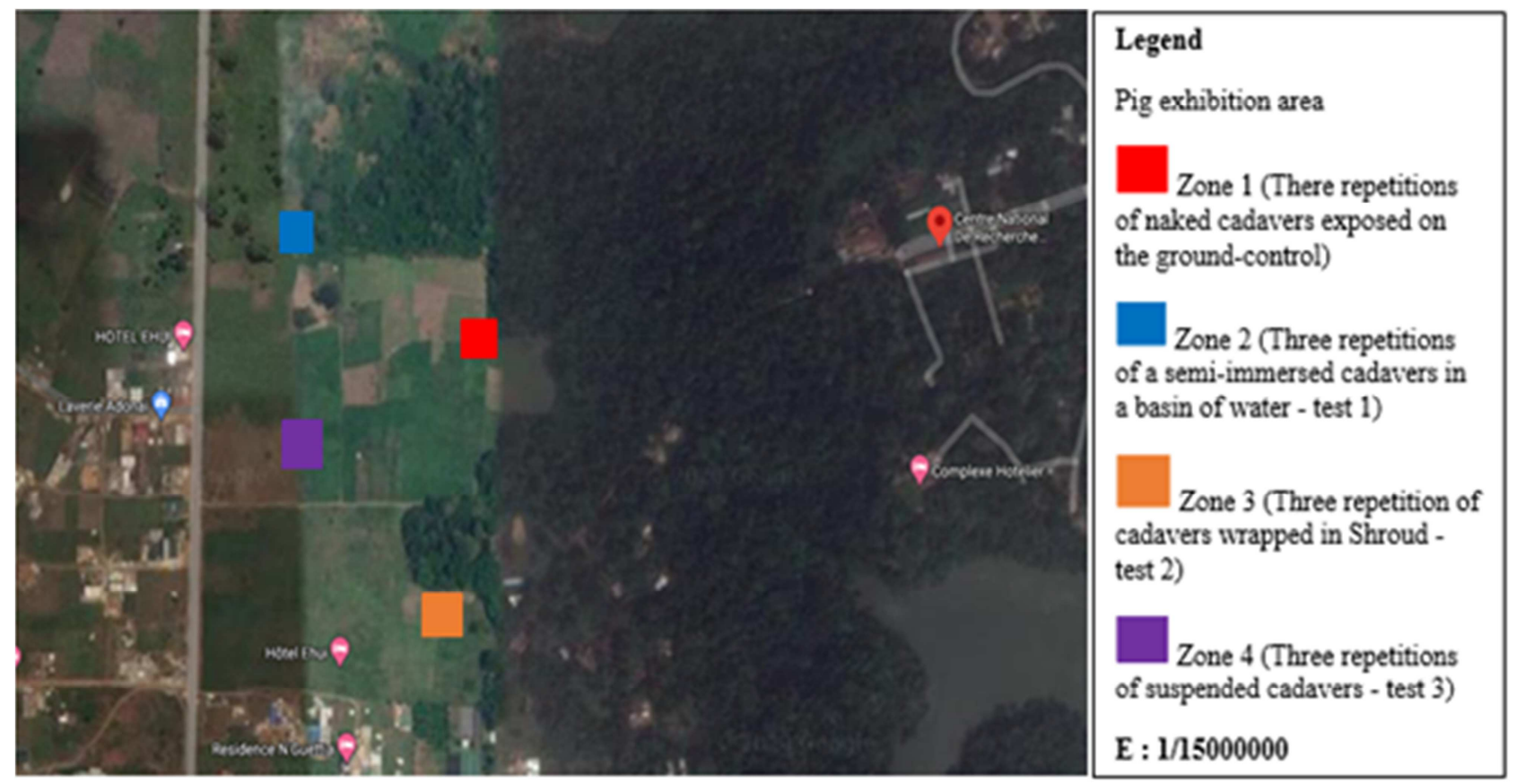

Figure 1. Satellite view of the study site [13].

\subsection{Experimental Climatic Conditions}

On the study site, a thermo-hygrometer recorder of the "IHM - 172SI" type was installed to record the daily temperatures and relative humidity. The Meteorological Service of the Airport, Aeronautical and Meteorological Exploitation and Development Company (SODEXAM Abidjan) provided rainfall data. The daily climatic data recorded were used to calculate the monthly averages of temperature and relative humidity as well as the monthly total rainfall. Temperatures were between 25 and $29^{\circ} \mathrm{C}$, and relative humidity between 77 and $85 \%$. The rainfall of the study period ranged from 10.2 to $292.61 \mathrm{~mm}$ of rain. However, here is no rain was recorded in the first seven postmortem days.

\subsection{Methods}

\subsubsection{Experimental Apparatus}

The experimental device consisted of four types of wire mesh cages corresponding to the following cases: corpses exposed to the open air or Control Cadavers (CC), SemiImmersed Cadavers (SIC), Cadavers Wrapped in a Shroud (CWS) and Suspended Cadavers (SPC). A freshly slaughtered pig was introduced into each cage. The dimensions of the cages of the first three cases were $\mathrm{L}=1.5$ $\mathrm{m}, \mathrm{l}=1 \mathrm{~m}$ and $\mathrm{h}=0.8 \mathrm{~m}$. Those of the cage housing the suspended corpse were $\mathrm{L}=0.9 \mathrm{~m}, \mathrm{l}=0.9 \mathrm{~m}$ and $\mathrm{h}=1.5 \mathrm{~m}$.

The dimensions of the basin were $\mathrm{L}=1.7 \mathrm{~m}, \mathrm{l}=1.2 \mathrm{~m}$ and the pool depth $0.7 \mathrm{~m}$. Three $60 \mathrm{~kg}$ pigs corresponding to three repetitions were used in each case, ie a total of 12 pigs. 
Twelve (12) technicians were recruited for data collection,

one per repeat, or one data collector per exposed cadavers.
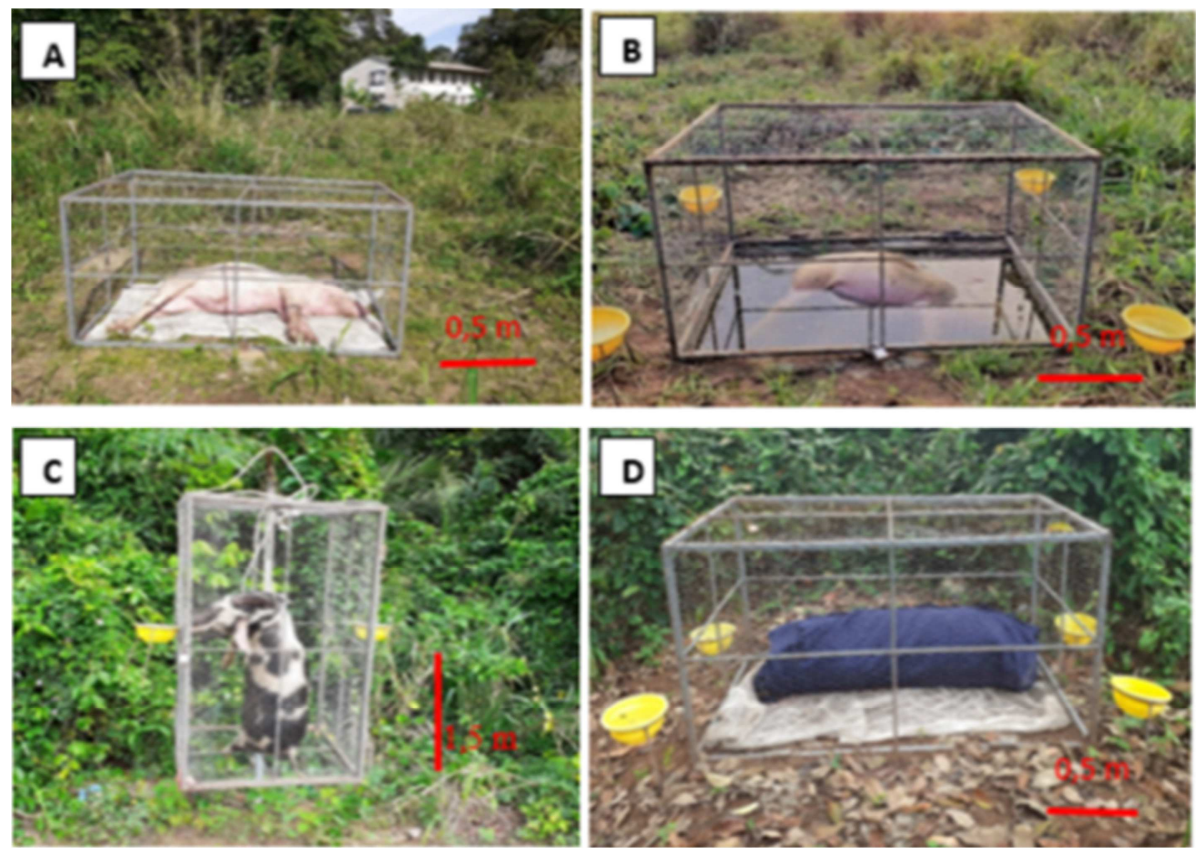

Figure 2. Exposure of the corpses in the various protection cages.

A: Exposure of the control cadavers, B: Exposure of the semi-immersed cadavers C: Exposure of the suspended cadavers, D: Exhibition of the wrapped cadavers.

\subsubsection{Egg-laying Delay on Corpses Exposed in Different Types of Cages}

1) Exhibition of pig carcasses

After the slaughter on October 29, 2019, noted day 0 (D0), the pigs were exposed in different situations and separated from each other by a distance of $300 \mathrm{~m}$ in an area comprising three repetitions. The zones were separated from each other by a distance of $800 \mathrm{~m}$ on the same site. The aim of this distancing was to avoid a possible phenomenon of competition in the process of colonization of the various corpses by the necrophagous Diptera.

2) Collection of eggs laid by the necrophagous Diptera

Observations were made every 30 minutes. It was a question of recording, using the technical sheets, the time of the first laying. Pictures were taken with a digital camera from the exposure of the pigs to the laying of the female Diptera. The collection of data relating to the laying of eggs and their samples was carried out from October 29, 2019 to November 05, 2019.

3) Breeding in the laboratory

The clusters of eggs laid by female necrophagous Diptera on pig carcasses were removed five times using a knife and flexible forceps. They were then incubated on a substrate, in plastic tubs containing sand sterilized in an autoclave at $121^{\circ} \mathrm{C}$ and at a pressure of 1.5 bar. The sand was lightly moistened and covered with muslin. After the eggs hatched, these boxes were placed in breeding tanks and sent to the laboratory. The larvae which came out were fed with $300 \mathrm{~g}$ of pork liver. These larvae were followed until pupae were obtained. After sorting, these pupae were grouped together by resemblance and then introduced into different cages and monitoring was done until the emergence of adult flies. Twenty-four hours after emergence, the flies obtained were killed by asphyxiation using carbon dioxide gas (CO2) then sorted, stung and identified. Then, the egg-laying delay of the species was determined.

4) Preparation and identification of emerged Diptera

The preparation of the emerged Diptera consisted in pricking them carefully mounted on an emalene flake fixed by an entomological pin. All the prepared specimens were kept in a sorting box.

The identification was made using a binocular magnifier of the brand "Optika LAB20 ". Identification keys were used to determine the various emerged species [3, 14-24].

\subsection{Data Processing}

1) Specific wealth (S)

The specific richness or total richness of a Biocenosis corresponds to the total number of all the species observed during $\mathrm{N}$ surveys [25].

$$
\mathrm{S}=\mathrm{Sp} 1+\mathrm{Sp} 2+\ldots+\mathrm{Spn}
$$

Where S: Total number of species observed during N surveys; $\mathrm{Sp} 1, \mathrm{Sp} 2$, Spn are the species collected.

2) Frequency of occurrence

The frequency of occurrence $(\mathrm{C})$ represents the ratio between the number of records where the species is found $(\mathrm{Pi})$ and the total number of records $(\mathrm{P})[26]$.

$$
\mathrm{C}(\%)=\mathrm{Pi} / \mathrm{P} \times 100
$$

There are 5 classes of frequency of occurrence: 
a) Ubiquitous species ( $\mathrm{C}=100 \%)$

b) Constant species $(50 \% \leq \mathrm{C}<100 \%)$

c) Common species $(25 \% \leq \mathrm{C}<50 \%)$

d) Accessory species $(5 \% \leq \mathrm{C}<25 \%)$

e) Rare species $(\mathrm{C}<5 \%)$

3) Statistical analyzes

The software Statistica version 7.1 was used to perform ANOVA variance analyzes. The Newman-Keuls test, at the $5 \%$ probability threshold, allowed to separate the different average of egg-laying delay of different species on the different cadavers.

\section{Results and Discussion}

\subsection{Results}

\subsubsection{Ecological Indices}

1) Specific wealth

The rearing carried out from the eggs collected made it possible to identify thirteen (13) species of Diptera from all the corpses exposed. These species have been grouped into four (4) families: the Calliphoridae (Calliphora vomitoria, Calliphora vicina, Chrysomya albiceps, Chrysomya marginalis, Chrysomya megacephala, Chrysomya putoria,
Lucilia caesar, Lucilia sericata and Protophormia terraenovae), the Muscidae (Musca domestica) the Sarcophagidae (Sarcophaga haerromoidalis and Sarcophaga carnaria) and the Fanniidae (Fannia canicularis). Of these, the Calliphoridae family has been the most diverse.

2) Frequency of occurrence

The frequency of occurrence in the case of pork witness showed that of the five (5) egg samples taken, the species: $C$. albiceps, C. marginalized, L. caesar, have been ubiquitous; or a frequency of occurrence of $100 \%$. That of $C$. vomitoria, $C$. putoria, L. sericata, $P$. terraenovae and $S$. carnaria was $40 \%$. The species $C$. vicina, C. megacephala, M. domestica, $S$. haerromoidalis, $F$. canicularis) were respectively present in $60 \%, 80 \%$, and $20 \%$ of cases (Table 1). On the corpses hanging cadaver, $100 \%$ of sampled eggs were those of $C$. albiceps and L. caesar. While species such as $C$. vomitoria, C. putoria, Lucilia sericata and S. haerromoidalis had a frequency of occurrence of $20 \%$. The species Calliphora vicina, C. megacephala, $P$. terraenovae and $S$. carnaria presented an occurrence rate of $40 \%$ while that of $C$. marginalis was $80 \%$. Musca domestica, F. canicularis, were rare on hanging cadavers $(\mathrm{C}=0 \%)$ (Table 1$)$.

Table 1. Frequency of occurrence of the different species at the level of each case.

\begin{tabular}{|c|c|c|c|c|c|c|c|c|c|c|}
\hline \multirow{2}{*}{ Families } & \multirow{2}{*}{ Species } & \multicolumn{2}{|c|}{$\begin{array}{l}\text { Control Cadavers } \\
\text { (CC) }\end{array}$} & \multicolumn{2}{|c|}{$\begin{array}{l}\text { Suspended } \\
\text { Cadavers (SPC) }\end{array}$} & \multicolumn{2}{|c|}{$\begin{array}{l}\text { Wrapped Cadavers } \\
\text { in a Shroud (WCS) }\end{array}$} & \multicolumn{2}{|c|}{$\begin{array}{l}\text { Semi-Immersed } \\
\text { Cadavers (SIC) }\end{array}$} & \multirow{2}{*}{$\begin{array}{l}\text { Numbers of } \\
\text { eggs sampling }\end{array}$} \\
\hline & & Nber of app & $\mathrm{C}(\%)$ & $\begin{array}{l}\text { Nber of } \\
\text { app }\end{array}$ & $\mathrm{C}(\%)$ & $\begin{array}{l}\text { Nber of } \\
\text { app }\end{array}$ & $\mathrm{C}(\%)$ & Nber of app & $\mathrm{C}(\%)$ & \\
\hline \multirow{9}{*}{ Calliphoridae } & Calliphora vomitoria & 2 & 40 & 1 & 20 & 2 & 40 & 1 & 20 & 5 \\
\hline & Calliphora vicina & 3 & 60 & 2 & 40 & 1 & 20 & 2 & 40 & 5 \\
\hline & Chrysomya albiceps & 5 & 100 & 5 & 100 & 5 & 100 & 5 & 100 & 5 \\
\hline & Chrysomya marginalis & 5 & 100 & 4 & 80 & 5 & 100 & 2 & 40 & 5 \\
\hline & Chrysomya megacephala & 4 & 80 & 2 & 40 & 3 & 60 & 1 & 20 & 5 \\
\hline & Chrysomya putoria & 2 & 40 & 1 & 20 & 1 & 20 & 1 & 20 & 5 \\
\hline & Lucilia caesar & 5 & 100 & 5 & 100 & 5 & 100 & 4 & 80 & 5 \\
\hline & Lucilia sericata & 2 & 40 & 1 & 20 & 1 & 20 & 1 & 20 & 5 \\
\hline & Protophormia terraenovae & 2 & 40 & 2 & 40 & 3 & 60 & 2 & 40 & 5 \\
\hline Muscidae & Musca domestica & 4 & 80 & 0 & 0 & 4 & 80 & 1 & 20 & 5 \\
\hline Sarcophagidae & Sarcophaga carnaria & 2 & 40 & 2 & 40 & 2 & 40 & 1 & 20 & 5 \\
\hline Fanniidae & Fannia canicularis & 1 & 20 & 0 & 0 & 2 & 40 & 1 & 20 & 5 \\
\hline
\end{tabular}

Nber of app: Number of apparition.

Concerning the wrapped cadavers, the frequency of occurrence was $100 \%$ for species such as $C$. albiceps, $C$. marginalis, L. caesar. It was $20 \%$ for species such as $C$. vicina, C. putoria and L. sericata. While some species such as $C$. vomitoria, $S$. carnaria and $S$. haerromoidalis showed a frequency of occurrence of $40 \%$, other species such as $C$. megacephala, $P$. terraenovae, and Musca domestica respectively exhibited a frequency of $60 \%$ occurrence, $80 \%$ (Table 1).

The frequency of occurrence in the case of the semisubmerged pig was $100 \%$ for the species $C$. albiceps, while it was $40 \%$ for the species such as $C$. vicina, $C$. marginalis and $P$. terraenovae. The species $C$. vomitoria, C. megacephala, C. putoria, L. sericata, M. domestica, S. carnaria, S. haerromoidalis, $F$. canicularis were common in $20 \%$ of cases (Table 1).

\subsubsection{Time Taken by Necrophagous Diptera to Lay Eggs After Slaughter and Exposure of Corpses}

The egg-laying delay of $C$. vomitoria on the control cadavers, suspended cadavers, wrapped cadavers and semiimmersed have respectively was $8.66 \pm 1.76,12.00 \pm 0.57$, $11.00 \pm 0.58$ and $11.66 \pm 1.45$ hours. The ANOVA test followed by that of Newman Keuls at the 5\% level did not reveal any significant difference between the egg-laying delay of this species at the level of the different situations $(\mathrm{F}=1.5346$, $\mathrm{df}=3, \mathrm{P}=0.278801$ ) (Table 2).

The egg-laying delay of $C$. vicina on control cadavers, 
hanging cadavers, wrappeded cadavers and semi-immersed cadavers have respectively was $7.00 \pm 0.57,8.66 \pm 0.88$; $10.66 \pm 1.45$ and $12.33 \pm 0.88$ hours $(\mathrm{F}=5.4074, \quad \mathrm{df}=3$, $\mathrm{P}=0.025101$ ) (Table 2).

At Chrysomya albiceps, the egg-laying delay were $10.33 \pm 1.20$ hours on the control cadavers, $11.66 \pm 1.21$ hours on suspended cadavers, $18.66 \pm 1.45$ hours on semi-immersed cadavers and $28.33 \pm 2.18$ hours on wrapped cadavers. The
ANOVA test followed by that of Newman Keuls at the 5\% threshold showed a significant difference between the egglaying delay of this species at the level of the different situations $(\mathrm{F}=27.7992, \mathrm{df}=3, \mathrm{P}=0.000139)$ (Table 2).

The egg-laying delay of $C$. megacephala on control, suspended, wrapped and semi-immersed cadavers were $11.00 \pm 1.52$ respectively, $11.00 \pm 1.15, \quad 11.33 \pm 0.88$ and $9.33 \pm 1.45$ hours $(\mathrm{F}=0.4972, \mathrm{df}=3, \mathrm{P}=0.694381)$ (Table 2).

Table 2. Egg-laying delay of the Families of the first necrophagous Diptera on corpses exposed under different conditions.

\begin{tabular}{|c|c|c|c|c|c|c|c|c|}
\hline \multirow[b]{2}{*}{ Families } & \multirow[b]{2}{*}{ Species } & \multicolumn{4}{|c|}{ Necrophagous Diptera egg-laying delay (hours) } & \multirow[b]{2}{*}{ df } & \multirow[b]{2}{*}{$\mathbf{F}$} & \multirow[b]{2}{*}{$\mathbf{P}$} \\
\hline & & $\begin{array}{l}\text { Control } \\
\text { Cadavers }\end{array}$ & $\begin{array}{l}\text { Suspended } \\
\text { Cadavers }\end{array}$ & $\begin{array}{l}\text { Wrapped Cadavers } \\
\text { in a Shroud }\end{array}$ & $\begin{array}{l}\text { Semi-Immersed } \\
\text { Cadavers }\end{array}$ & & & \\
\hline \multirow{8}{*}{ Calliphoridae } & Calliphora vomitoria & $8.66 \pm 1.76^{\mathrm{a}}$ & $12.00 \pm 0.57^{\mathrm{a}}$ & $11.00 \pm 0.58^{\mathrm{a}}$ & $11.66 \pm 1.45^{\mathrm{a}}$ & 3 & 1.5346 & 0.278801 \\
\hline & Calliphora vicina & $7.00 \pm 0.57^{\mathrm{b}}$ & $12.00 \pm 1.73^{\mathrm{b}}$ & $10.66 \pm 1.45^{\mathrm{ab}}$ & $12.33 \pm 0.88^{\mathrm{a}}$ & 3 & 5.4074 & 0.025101 \\
\hline & Chrysomya albiceps & $10.33 \pm 1.20^{\mathrm{c}}$ & $11.66 \pm 1.21^{\mathrm{c}}$ & $28.33 \pm 2.18^{\mathrm{a}}$ & $18.66 \pm 1.45^{\mathrm{b}}$ & 3 & 27.7992 & 0.000139 \\
\hline & Chrysomya marginalis & $8.33 \pm 0.88^{b}$ & $8.66 \pm 0.88^{\mathrm{ab}}$ & $21.66 \pm 2.40^{\mathrm{a}}$ & $12.00 \pm 0.57^{\mathrm{b}}$ & 3 & 13.1985 & 0.001827 \\
\hline & Chrysomya megacephala & $11.00 \pm 1.52^{\mathrm{a}}$ & $11.00 \pm 1.15^{\mathrm{a}}$ & $11.33 \pm 0.88^{\mathrm{a}}$ & $9.33 \pm 1.45^{\mathrm{a}}$ & 3 & 0.4972 & 0.694381 \\
\hline & Lucilia caesar & $6.66 \pm 0.88^{\mathrm{c}}$ & $10.33 \pm 0.88^{b}$ & $12.33 \pm 0.87^{\mathrm{a}}$ & $8.00 \pm 0.57^{\mathrm{bc}}$ & 3 & 9.4444 & 0.005249 \\
\hline & Lucilia sericata & $9.33 \pm 1.76^{\mathrm{a}}$ & $9.33 \pm 1.20^{\mathrm{a}}$ & $10.00 \pm 1.52^{\mathrm{a}}$ & $12.66 \pm 0.88^{\mathrm{a}}$ & 3 & 1.3140 & 0.335465 \\
\hline & Protophormia terraenovae & $26.00 \pm 1.57^{\mathrm{a}}$ & $12.66 \pm 4.35^{\mathrm{a}}$ & $30.66 \pm 3.52^{\mathrm{a}}$ & $22.66 \pm 4.09^{\mathrm{a}}$ & 3 & 3.2346 & 0.081864 \\
\hline \multirow{3}{*}{ Sarcophagidae } & Musca domestica & $12.26 \pm 1.25^{\mathrm{b}}$ & - & $20.33 \pm 1.85^{\mathrm{a}}$ & $18.66 \pm 2.60^{\mathrm{a}}$ & 3 & 28.9037 & 0.000121 \\
\hline & Sarcophaga carnaria & $12.66 \pm 1.76^{\mathrm{c}}$ & $19.00 \pm 2.88^{\mathrm{b}}$ & $11.00 \pm 0.57^{\mathrm{c}}$ & $32.33 \pm 0.88^{\mathrm{a}}$ & 3 & 29.9086 & 0.000107 \\
\hline & Sarcophaga haerromoidalis & $9.00 \pm 1.52^{b}$ & $30.66 \pm 2.96^{\mathrm{a}}$ & $11.33 \pm 0.88^{\mathrm{b}}$ & $12.33 \pm 0.87^{\mathrm{b}}$ & 3 & 31.4971 & 0.000088 \\
\hline Fanniidae & Fannia canicularis & $170.66 \pm 2.18^{\mathrm{a}}$ & - & $174.00 \pm 3.61^{\mathrm{a}}$ & $136.00 \pm 8.32^{\mathrm{b}}$ & 3 & 308.250 & 0.000000 \\
\hline
\end{tabular}

The numbers followed by the same letter, in the same line, are not significantly different according to the Newman-Keuls test at the $5 \%$ level.

Chrysomya marginalis laid its first eggs on the control cadavers, $8.33 \pm 0.88$ hours after exposure, on the suspended cadavers, after $12.00 \pm 1.73$ hours post-mortem, at the level of the wrapped cadavers, $21.66 \pm 2.40$ hours after exposure and on semi-submerged cadavers, after $12.00 \pm 0.57$ post-mortem. The ANOVA test followed by that of Newman Keuls at a threshold of $5 \%$ showed a significant difference between the times to lay eggs of this species at the level of the different situations $(\mathrm{F}=13.1985, \mathrm{df}=3, \mathrm{P}=0.001827)$ (Table 2$)$.

The egg-laying delay of $C$. putoria on control cadavers, suspended, packaged and semi-immersed have respectively been 16. $33 \pm 2.60,18.66 \pm 4.81,48.00 \pm 2.01$ and $32.33 \pm 4.09$ hours $(\mathrm{F}=16.8216, \mathrm{df}=3, \mathrm{P}=0.000814)$ (Table 2).

The egg-laying delay for $L$. caesar were $6.66 \pm 0.88$ hours on the control cadavers, $10.33 \pm 0.88$ hours on suspended cadavers, $12.33 \pm 0.87$ hours on wrapped cadavers and $8.00 \pm 0.57$ hours on semi-immersed cadavers $(\mathrm{F}=9.4444$, $\mathrm{df}=3, \mathrm{P}=0.005249$ ) (Table 2).

In $L$. sericata, the egg-laying delay were $9.33 \pm 1.76$ hours, on the control cadavers, $9.33 \pm 1.20$ hours on suspended cadavers, $10.00 \pm 1.52$ hours for wrapped cadavers and $12.66 \pm 0.88$ hours for semi-immersed cadavers. The ANOVA test followed by that of Newman Keuls at the 5\% threshold showed a significant difference between the egg-laying delay of this species at the level of the different situations $(\mathrm{F}=1.3140$, $\mathrm{df}=3, \mathrm{P}=0.335465$ ) (Table 2). Protophormia. terraenovae laid its first eggs on the control cadavers $26.00 \pm 1.57$ hours after exposure, on the suspended corpses, after $12.66 \pm 4.35$ hours post mortem, at the level of the wrapped cadavers, $30.66 \pm 3.52$ hours after exposure and $22.66 \pm 4.09$ hours post mortem on semi-immersed cadavers $(\mathrm{F}=3.2346, \mathrm{df}=3, \mathrm{P}=0.081864)$ (Table
2).

The egg-laying delay of $M$. domestica were respectively was $12.26 \pm 1.25$ hours, $20.33 \pm 1.85$ hours and $18.66 \pm 2.60$ hours on control cadavers, packaged and semi-immersed. On the other hand, no spawning of $M$. domestica was observed on the suspended cadavers $(\mathrm{F}=28.9037, \mathrm{df}=3, \mathrm{P}=0.000121)$ (Table 2).

In Sarcophaga carnaria, the egg-laying delay were $12.66 \pm 1.76$ hours on the control cadavers, $19.00 \pm 2.88$ hours on the suspended cadavers, $11.00 \pm 0.57$ hours on the wrapped cadavers and $32.33 \pm 0.88$ hours on the semi-immersed cadavers. The ANOVA test followed by that of Newman Keuls at the $5 \%$ threshold showed a significant difference between the delay to lay eggs for this species at the level of the different situations $(\mathrm{F}=29.9086, \mathrm{df}=3, \mathrm{P}=0.000107)$ (Table 2).

The delay of egg-laying of $S$. haerromoidalis on control, suspended, wrapped and semi-immersed corpses were $9.00 \pm 1.52$ respectively, $30.66 \pm 2.96, \quad 11.33 \pm 0.88$ and $12.33 \pm 0.87$ hours $(\mathrm{F}=31.4971, \mathrm{df}=3, \mathrm{P}=0.000088)$ (Table 2). The egg-laying delay of Fannia canicularis have respectively been 170, $66 \pm 2.18$ hours, $174.00 \pm 136.00 \pm 3.61$ hours and 8.32 hours on the control cadavers, wrapped cadavers and semi- immersed cadavers. On the other hand, no eggs of this species were taken from the suspended cadavers $(\mathrm{F}=308.250$, $\mathrm{df}=3, \mathrm{P}=0.00001$ ) (Table 2).

\subsection{Discussion}

The pig cadavers used in our experiments were exposed under different experimental conditions (control cadavers exposed to the open air, cadavers suspended in the open air, 
semi-immersed cadavers and wrapped cadavers). These were exposed at specific sites separated by at least $300 \mathrm{~m}$ from each other, so that colonization of carcasses by necrophagous Diptera was not influenced by any phenomenon of intraspecific competition. The 13 species of necrophagous Diptera identified each exhibited an egg-laying delay that varied from one species to another and from one type of cadaver to another. The rapid drying out of the suspended corpses and their position did not allow Diptera belonging to the Muscidae ( $M$. domestica) and Fanniidae (F. canicularis) families to carry out their first eggs. These desiccated corpses were no longer attractive to the rest of the necrophagous Diptera seeking to lay eggs [11].

A few hours after the slaughter and exposure of the pig corpses according to each situation, many adults of Diptera belonging to the families of Calliphoridae, Sarcophagidae and Muscidae were attracted by the first odors emitted by the onset of decomposition. The early appearance of these Diptera families on exposed corpses could be explained by their particularly developed chemotactile system (olfactory system), allowing them to detect very weak odors several tens of meters away [8, 12, 25-29] have also observed this early colonization of corpses by species from these families. Many species are associated with the cadaver ecosystem and in particular, adult females of necrophagous Diptera, in search of protein inputs necessary for vitellogenesis [30]. The early arrival of species from these Diptera families could also be due to favorable climatic conditions. Among these pioneer species, we find mostly Calliphoridae Diptera [9, 12]. During our observations, the egg-laying took place in very hidden areas. In the control corpses, the necrophagous Diptera laid their eggs on the back facing the ground. Concerning the suspended corpses, the laying was carried out in the mouth, the snout and the hollow of the eyes. In the case of wrapped corpses, the eggs laid were observed on the tissue covering the head and in semiimmersed corpses, the first eggs were laid in the hollows of the hind legs and the ear. This behavior, which had also been described by [31] during his work on Pig97 and Pig99, would be at the origin of the choice of place of egg-laying of females. These would act in this way to protect their eggs against the light intensity and heat of the sun $[9,12]$.

In the species of Diptera Calliphoridae recorded on corpses exposed in different situations, an order of appearance was observed. When we consider the $C$. marginalis egg-laying time, we notice that it was $8.33 \pm 0.88$ hours on the control corpses, $8.66 \pm 0.88$ hours on the suspended corpses, $12.00 \pm 0.57$ on semi-immersed corpses and $21.66 \pm 2.40$ hours on wrapped corpses, at an ambient temperature varying between 25.6 and $29.8^{\circ} \mathrm{C}$ and at a relative humidity ranging from 78.7 to $89 \%$. Although the corpses were subjected to identical environmental and climatic conditions, a significant difference was observed in the laying time of $C$. marginalis. This could be explained by the variation in accessibility to corpses. Indeed, the witness and suspended corpses being exposed to the open air, were the first to be colonized by necrophagous insects. The semi-immersed corpses followed in second position with a delay of 3 hours 30 minutes compared to the time obtained for the control and suspended corpses. This delay is mainly due to the reduction in available laying sites, which delayed the access to the semiimmersed corpses. When the bodies were placed in the water, they have first been immersed in $4 / 5$ of their volume and this is from the 8 hours post mortem they have begun to emerge [32]. The progressive swelling of pig corpses is believed to be the cause of the late emergence of carcasses from the water. This late corp ses emergence has favored the emergence of laying sites of necrophagous Diptera. The delay taken to lay eggs for these different Diptera varied from one species to another. This variability in the laying delay could be explained by the fact that these carcasses had only a small part of the laying sites and that the water closed the rest of the body. It was therefore difficult for some Diptera to access the corpses despite their presence. The presence of water around the corpses would influence the accessibility of Diptera to the substrate. Indeed, water was an obstacle to the activity of flies because they looked for sites favorable to the development of their offspring.

On the control cadavers, suspended cadavers, wrapped cadavers and semi-immersed cadavers, the first eggs of $S$. carnaria respectively were observed at $12.66 \pm 1.76$; $19.00 \pm 2.88 ; \quad 11.00 \pm 0.57$ and $32.33 \pm 0.88$ hours after exposure of the carcasses. The late laying in semi-immersed corpses could be explained by the same causes. The slight difference observed in the egg-laying time of this species (larviparous) on suspended corpses is due to the search for a favorable site to deposit their larvae, in order to ensure their development.

Other species of Diptera such as $M$. domestica (Muscidae) and F. canicularis (Fanniidae) were observed a little later on the other three types of pig carcasses with the exception of the suspended corpses which where the latter carried out no laying. The late arrival of these species is said to be due to the characteristic odors emitted by the decomposing corpses. Indeed, these same species were also collected late on decaying corpses exposed to the open air by [9, 12]. The absence of activity by Muscidae and Fanniidae in the suspended corpses could be explained by the drying out of these. Indeed, when the corpses become dry, the insects no longer have nutrients favorable to the proper development of the larvae of these species. These observations join those of [12] who carried out work on corpses exposed to the open air in the Sub-Sudanese zone of Côte d'Ivoire during the dry and rainy seasons.

As decomposition is strongly linked to the characteristics of the cadaver ecosystem, insect succession is therefore highly variable [7]. It depends on the environmental conditions and the initial state of the corpse, but other factors such as the action of plants, fungi or carnivorous mammals may intervene [5].

\section{Conclusion}

Thirteen (13) identified species of necrophagous Diptera which laid eggs on exposed corpses were grouped into four families: the Calliphoridae $(C$. vomitoria, $C$. vicina, $C$. 
albiceps C. marginalis, C. megacephala, C. putoria, L. caesar, L. sericata and $P$. terraenovae), Muscidae ( $M$. domestica), Sarcophagidae (S. haerromoidalis, S. carnaria) and Fanniidae (F. canicularis). Of these, Calliphoridae family has been the most diverse.

Regarding the egg-laying delay in species of Calliphoridae (L. caesar and C. vicina) was shorter on control and suspended corpses or respectively $6.66 \pm 0.88$ and $8.66 \pm 0,88$ hours after slaughter and exposure of the corpses.

On semi-immersed and wrapped cadavers, the first egglaying respectively observed after $8.00 \pm 0.57$ and $10.66 \pm 1.45$ hours post mortem, were those of Lucilia caesar and Calliphora vicina.

The Muscidae and the Fanniidae, which appeared later on the decomposing corpses, were not observed on the suspended corpses which very quickly dried up and therefore could no longer provide the nutrients essential for the proper development of the larvae of the species of these families of Diptera. The species laid eggs on the hidden parts of the exposed corpses to allow protection of the eggs from solar radiation and the intensity of light.

At the end of this study, we can retain that according to the accessibility of the insects to the corpses to the necrophagous insects, the first Diptera egg-laying was observed at least six hours $(6 \mathrm{~h})$ and at most 174 hours after exposure of the carcasses [33]. Thus, it clearly appears that the conditions of exposure of pig cadavers significantly influenced the egglaying delay of the main necrophagous Diptera [34]. As part of an entomological expertise to date deaths in the Guinean zone of Côte d'Ivoire, these variable of egg-laying delay for the first Diptera should be taken into account in estimating the minimum post-mortem interval upon discovery of a corpse.

\section{Acknowledgements}

We would like to thank the Director General of the National Agronomic Research Center for allowing us to carry out our work on the CNRA- Adiopodoumé Km 17 site. We also thank the Director of the National Institute of Public Hygiene who provided us a laboratory.

\section{Declaration}

The authors declare that they have no conflict of interest regarding this article.

\section{References}

[1] Amendt J., Krettek R. \& Zehner R., 2004. Forensic entomology, Naturwissenschaften 91 (2004) 51-65.

[2] Goff, M. L. 2009. Early post-mortem changes and stages of decomposition in exposed cadavers. Experimental and Applied Acarology, 49, 2136.

[3] Wyss C. \& Chérix D., 2006. Treatise on Forensic Entomology, 1st Edition. Presses Polytechniques et Universitaires
Romandes, Lausanne, Switzerland, 317 p.

[4] Gaudy. E \& Dourel L., 2009. Forensic Entomology: A Time Machine. Institute of Criminal Research of the National Gendarmerie.

[5] Campobasso C. P., Di Vella G. \& Introna F., 2001. Factors affecting decomposition and Diptera colonization. Forensic Science International, 120 (1-2): 18-27.

[6] Hamel. K., 2011. Contribution to the study of the influence of temperature on the development of necrophagous insects $59 \mathrm{p}$.

[7] Wells J. D. \& Lamotte L. R., 1995. Estimating maggot age from weight using inverse prediction. Journal of Forensic Sciences, 40 (4): 585-590.

[8] Koffi A. F., Aboua L. R. N., Dao H., Djodjo M., Koffi-Tébélé J. D. E. \& Kpama-Yapo C. E. Y., 2017 a. Process of colonization by necrophagous insects, of a pig corpse exposed at the open air in southern forest zone of Côte d'Ivoire. International Journal of Current Research and Academic Review 5 (7): 103-114.

[9] Koffi A. F., Aboua L. R. N., Dao H., Djodjo M., Koffi-Tébélé J. D. E. \& Mian A. K., 2018. Inventory of necrophagous insects involved in the decomposition process of a pig corpse (Sus scrofa domesticus L.) exposed to the open air in the southern forest zone of Côte d'Ivoire. European journal of biomedical and pharmaceutical science, 5 (01) 51-62.

[10] Dao H., Aboua L. R. N., Koffi A. F. \& Kpama-Yapo C. E. Y., 2017. Biological parameters of Sarcophaga carnaria L. (Diptera: Sarcophagidae), necrophagous fly breeding on two pig substrates (Sus scrofa domesticus L.) at the national floristic center, Abidjan, Côte d'Ivoire. International Journal of Research and Development Organisation, 3 (1): 1-16.

[11] Dao H., Aboua L. R N., Koffi A. F., Agboka K., Tuo Y. \& Yapo Y. E. C. Epouse-Kpama, 2018. Influence of the ecological zone on the necrophagous insects' activities involved in the process of decomposition of pig carcasses (Sus scrofa domesticus L.) exposed to the open air in the subsudanese zone of Côte d'Ivoire. International Journal of Entomology Research, 3 (5) 07-16.

[12] Dao H., Aboua L. R. N., Agboka K., Koffi A. F. \& Djodjo M., 2019. Influence of the seasons on the activity of necrophagous insects in the decomposition process of dead pigs (Sus scrofa domesticus L.) exposed to the open air in the sub-Sudanese zone of Côte d'Ivoire. Africa SCIENCE 15 (1) 361-376.

[13] Anonyme, 2020. CNES image data, Accessed 08/12/2020.

[14] Prins A. J., 1982. Morphological and biological notes on six South African Blow-flies (Diptera: Calliphoridae) and their immature stages. Annals of the South Africa Museum, 90 (1982): 201-217.

[15] Smith K. G. V., 1986. A manual of forensic entomology. British Museum (Natural History), London and Cornell University Press, Ithaca, N. Y., 205 p.

[16] Delvare G. \& Alberlenc H. P., 1989. Insects from Africa and tropical America: keys to family recognition. Book, CIRAD, $82 \mathrm{p}$.

[17] Couri S. M., 2007. A key to the Afrotropical genera of Muscidae (Diptera). Revista Brasileira de Zoologia, 24 (1): 175-184.

[18] Claudio J. B. C. \& Cátia A. M. P., 2008. Key to the adults of the most common forensic species of Diptera in South America. Revista Brasileira d'Entomologia, 52 (3): 390-406. 
[19] Szpila K., 2009. Key for identification of European and Mediteranean blowflies (Diptera, Calliphoridae) of forensic importance Adult flies. Nicolaus Copernic University Institute of Ecology and Environnental Protection Departement of Animal Ecoogy, 2014, 18.

[20] Whitworth T., 2010. Keys to the genera and species of blow flies (Diptera: Calliphoridae) of the West Indies and description of a new species of Lucilia Robineau-Desvoidy. Zootaxa, 2663: 1-35.

[21] Irish S., Lindsay T. \& Wyatt N., 2014. Key to adults of Afrotropical species of the genus Chrysomya Robineau-Desvoidy (Diptera: Calliphoridae). African Entomology, 22 (2): 297-306.

[22] Rochefort S., Marjolaine Giroux, Jade Savage \& Terry A. Wheeler, 2015. Key to Forensically Important Piophilidae (Diptera) in the Nearctic Region Canadian Journal of Arthropod Identification 27 (1) 37p.

[23] Pintoe K Vairo, Mauricio Osvaldo Moura, Cátia Antunes de Mello-Patiu 2015. Comparative morphology and identification key for females of nine Sarcophagidae species (Diptera) with forensic importance in Southern Brazil, Revista Brasileira de Entomologia.; 59: 177-187.

[24] Ramade F., 1984. Elements of ecology. Fundamental ecology. Ed. Mc. Graw-Hill, Paris, France, 379 p.

[25] Dajoz R., 2000. Precise of ecology, 7th edition, Dunod, Paris, $615 \mathrm{pp}$.

[26] Braack L. E., 1987. Community dynamics of carrion-attendant arthropods in tropical African woodland. Oecologia, 72 (3): 402-409.
[27] Picimbon J. F., 2002. The chemosensory peri-receptors of insects. Medicine / Sciences, 18: 1089-1094.

[28] Kelling J., Biancaniello G. \& Den Otter C. J., 2003. Effect of age and sex on the sensitivity of antennal and palpal olfactory cells of houseflies. Entomologia Experimentalis et Applicata, 106 (1): 45-51.

[29] Dekeirsschieter J., 2007. Study of the odors emitted by decaying pig carcasses (Sus domesticus scrofa L.) and monitoring of post-mortem colonization by necrophagous insects. End of studies thesis. University Faculty of Agronomic Sciences of Gembloux, Belgium, $104 \mathrm{p}$.

[30] Silahuddin S. A., Baha L., Hiromu K., Chong C. H. \& Walter E., 2015. The Importance of Habitat in the Ecology of Decomposition on Rabbit Carcasses in Malaysia: Implications in Forensic Entomology. Journal of Medical Entomology, 52 (1): 9-23.

[31] Charabidze D. and Gosselin M., 2014. Insects, corpses and crime scenes. Principles and applications of forensic entomology. Ed. De Boeck., 261 p., 16 chapters.

[32] Dekeirsschieter J., Verheggen F. J., Haubruge E. \& Brostaux Y., 2011. Carrion beetles visiting pig carcasses during early spring in urban, forest and agricultural biotopes of Western Europe. Journal of Insect Science, 11 (73): 1-13.

[33] Boulay J., 2015. Study of the aggregation behavior of necrophagous Diptera larvae: from the individual to the collective. Thesis from the University of Lille II, Université Libre de Bruxelles. 151p.

[34] Wyss C., 2000. Entomological investigation 83-insp, determination of the post-mortem time: Annex 2. 